\title{
Sébastien Castellion, Les «Livres de Salomon» (1555)
}

\section{Michele Mastroianni}

\section{(2) OpenEdition}

\section{Journals}

\section{Edizione digitale}

URL: http://journals.openedition.org/studifrancesi/8214

DOI: $10.4000 /$ studifrancesi.8214

ISSN: 2421-5856

\section{Editore}

Rosenberg \& Sellier

\section{Edizione cartacea}

Data di pubblicazione: 1 mai 2009

Paginazione: 157

ISSN: 0039-2944

\section{Notizia bibliografica digitale}

Michele Mastroianni, «Sébastien Castellion, Les «Livres de Salomon» (1555)», Studi Francesi [Online], 157 (LIII | I) | 2009, online dal 30 novembre 2015, consultato il 09 janvier 2021. URL: http://

journals.openedition.org/studifrancesi/8214 ; DOI: https://doi.org/10.4000/studifrancesi.8214

\section{Questo documento è stato generato automaticamente il 9 janvier 2021.}

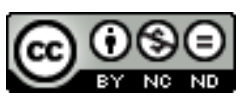

Studi Francesi è distribuita con Licenza Creative Commons Attribuzione - Non commerciale - Non opere derivate 4.0 Internazionale. 
Sébastien Castellion, Les «Livres de Salomon» (1555)

Michele Mastroianni 


\section{NOTIZIA}

SÉBASTIEN CASTELLION, Les «Livres de Salomon» (1555), édités, introduits et annotés par Nicole GUEUNIER et Max ENGAMMARE, Genève, Droz, 2008 («Textes Littéraires Français», 595), pp. 335.

Dopo La Genèse (Genève, Droz, TLF 553, 2003: cfr. questi «Studi», 145, 2005, p. 145) due degli editori di questo testo pubblicano ora un'altra porzione della Bible nouvellement translatée (1555) di Sébastien Castellion, quella che comprende i libri tradizionalmente attribuiti a Salomone: Les Proverbes, L'Ecclésiaste, Le Cantique des cantiques. L'avvenuta discussione della thèse di Carine Skupien Dekens (La syntaxe française dans la traduction de la Bible par S. C., Univ. de Neuchâtel, 2006, mentre questa recensione è redatta se ne attende la pubblicazione presso Droz) ha fornito gli editori di un ulteriore strumento per commentare i testi da loro pubblicati, soprattutto per quanto concerne l'esame linguistico delle traduzioni di Castellion, che, come si sa, furono oggetto di aspre critiche sia da parte dei traduttori 'umanisti' sia da parte dei correligionari dello stesso Castellion, che vide duramente condannato da Calvino il suo lavoro. Ciascuno dei tre libri veterotestamentari è preceduto da un'introduzione che situa il testo nel quadro della sua esegesi cinquecentesca, ne studia gli aspetti linguistici (con particolare attenzione alle tecniche di traduzione sul piano più propriamente lessicale), ne confronta la sintassi con quella degli originali (si fa notare, per esempio, per quanto concerne i Proverbi la tendenza a subordinare là dove l'ebraico giustappone, e si chiarisce la portata ideologica delle diversificazioni sintattiche), e soprattutto evidenzia il sustrato dottrinale di Castellion che condizione le sue scelte traduttologiche. Il testo è accuratamente annotato. Glossario e bibliografia concludono il lavoro. 